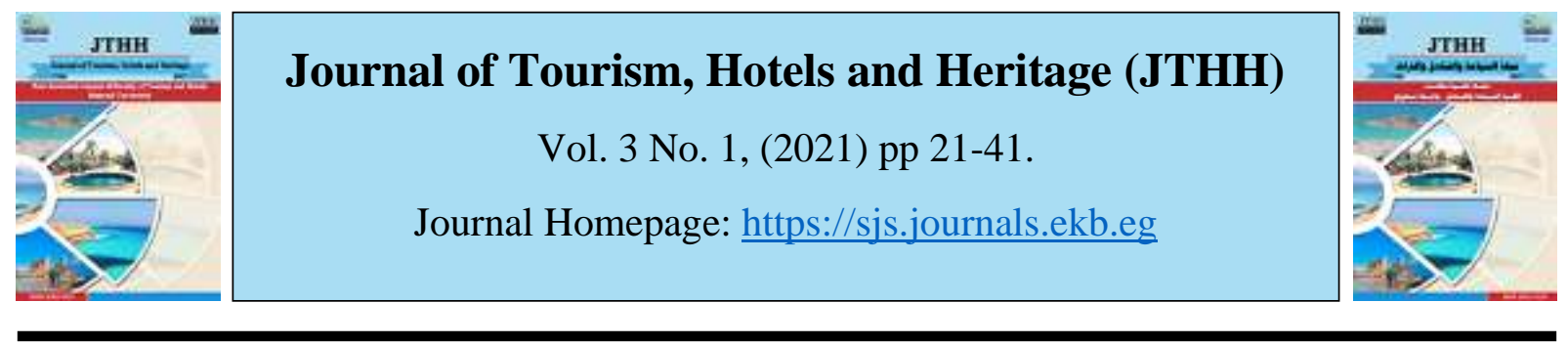

\title{
Managing Food Waste: What Happens After Food Waste Generation In Hotels?
}

\author{
Ahmed Rady ${ }^{1}$ \\ Mohamed Abo Taleb ${ }^{3}$ \\ Abd El-Bary Dawood ${ }^{2}$ \\ Mahmoud Adel $^{4}$ \\ ${ }^{1}$ Hotel Management Dep., Faculty of Tourism \& Hotels, Minia University \\ ${ }^{2}$ Hotel Management Dep., Faculty of Tourism \& Hotels, Minia University \\ ${ }^{3}$ Hotel Studies Dep., Faculty of Tourism \& Hotels, Sadat City University \\ ${ }^{4}$ Hotel Management Dep., Faculty of Tourism \& Hotels, Minia University
}

\section{ARTICLE INFO}

Keywords:

Managing Food Waste

Food Waste Generation Hotels

(JTHH)

Vol. 3 No. 1, (2021)

pp 21-41.

\begin{abstract}
Food Waste (FW) is an issue requiring urgent action throughout the world. FW is still the main concern for the hospitality industry where the exact amount of FW produced in tourism is uncertain. Managing FW includes all actions taken to reduce the amount of waste. It includes waste prevention, recycling, composting, and the purchase of products that have recycled content or produce less waste. This research aims to explore the applied FW management polices after FW generation in three, four, and fivestar hotels. A deductive approach and quantitative method research design using questionnaire survey for a sample of food and beverage department managers in three, four, and five-star hotels at Hurghada city were adopted. A total of 88 questionnaire forms were conducted among food and beverage department managers. Descriptive statistics, One-way ANOVA test, and independent sample T-test were used to analyze obtained data. The research revealed that there are many food waste management practices that are applied in many hotels, such as FW monitoring, FW reusing, and FW recycling. The research also showed some barriers faced hotels while managing FW such as the high cost of surplus food segregation, storing, transportation, and handling, concerns about the safety of animal feed, and the high cost of the recycling process. The research provided a set of recommendations to enhance the process of managing FW in hotels.
\end{abstract}

\section{Introduction}

The problem of global FW has recently received much interest (International Tourism Partnership, 2014; High-Level Panel of Experts, 2014; HOTREC Hospitality Europe, 2017; and Lasaridi et al., 2017). Because of the lack of resources, reducing FW and collecting it to produce food donations is now a top priority in the battle against hunger and poverty (International Tourism Partnership, 2014). 842 million people, or almost one in eight persons worldwide, suffered from chronic hunger in 2011-2013 (Herszenhorn et al., 2014). The high waste values in hotels are related to their traditional catering procedures, which include a high proportion of raw foods and offering extensive menus (Youngs et al., 1983). Tourism researchers have not given as much attention to the fact that FW is a major contributor to the tourism industry's negative impact on the environment as one could expect, given the magnitude of the problem 
in tourism (Selin, 2018). In addition, there are not many scholarly publications available regarding FW in the hospitality sector (Marthinsen et al., 2012). The majority of the data about FW in hospitality is available in the form of published reports (WRAP, 2011).

\section{Literature Review}

\section{FW definitions}

There is no universally agreed definition of FW (Lebersorger and Schneider, 2011), which makes it difficult to study and quantify FW (Buzby and Hyman, 2012). According to Gandhi et al. (2017); FW is defined as "The food, which was initially available for consumption by humans but was not consumed and besides this, it was kept beyond its expiry date or left to be spoiled, used for the feeding of animals or was disposed to feed an anaerobic digestion plant or incinerator". Also, Saputri et al. (2018) defined FW as "Losses that occur at retails, foodservice sectors and consumer stages".

\section{FW Generation in Hotels}

\section{Quantifying $F W$}

In the hotel industry, the waste created by hotels consists of glass, metal, carton, aluminum, plastics, and food (Abo-Taleb, 2005). FW is still the main concern for the hospitality industry (Nedyalkova, 2016). The exact amount of FW produced in tourism is uncertain, but it is estimated that hotels, restaurants, and the catering industry account for approximately $14 \%$ of the total annual FW created (Bio Intelligence Service, 2010). FW accounts for over $50 \%$ of the waste produced in the hospitality sector (Curry, 2012). The Scottish hospitality industry, e.g., is estimated to dispose of up to 53,500 tonnes of FW annually, two-thirds of which could have been consumed (Resource Efficient Scotland, 2014). FW could be measured in the food supply chain in three different ways-edible weight, economic value, and equivalent calories (loke, 2018). Using FW monitoring data regularly to set menus, address over-portioning, improve demand forecasting, identify where the waste arises, and provide important information to target specific causes for FW (Hollins, 2013).

\section{Managing $F W$}

Managing FW includes all actions taken to reduce the amount of waste. It includes waste prevention, recycling, composting, and the purchase of products that have recycled content or produce less waste (Georgia Hospitality Environmental Partnership, 1996). USEPA (2014a) and House of Commons (2017) confirmed that The Food Recovery Hierarchy (figure 1) sets out steps for managing FW to minimize the impact on the environment. The best action is to prevent raw materials, ingredients, and products from becoming waste in the first place. If surplus cannot be prevented, then redistribution to people and then the animal feed is the next best option. The best way of treating FW is to recycle it by sending it to anaerobic digestion or composting. Recovery through the incineration of waste with energy recovery comes next in the hierarchy. At the bottom of the hierarchy, the worst way of dealing with FW is disposal through waste incineration without energy recovery or sending it to a landfill. Creedon et al. (2010) and Buzby et al. (2014) stated that waste prevention incorporates the first three terms of The Food Recovery Hierarchy (source reduction, feed hungry people, and feed animals). 


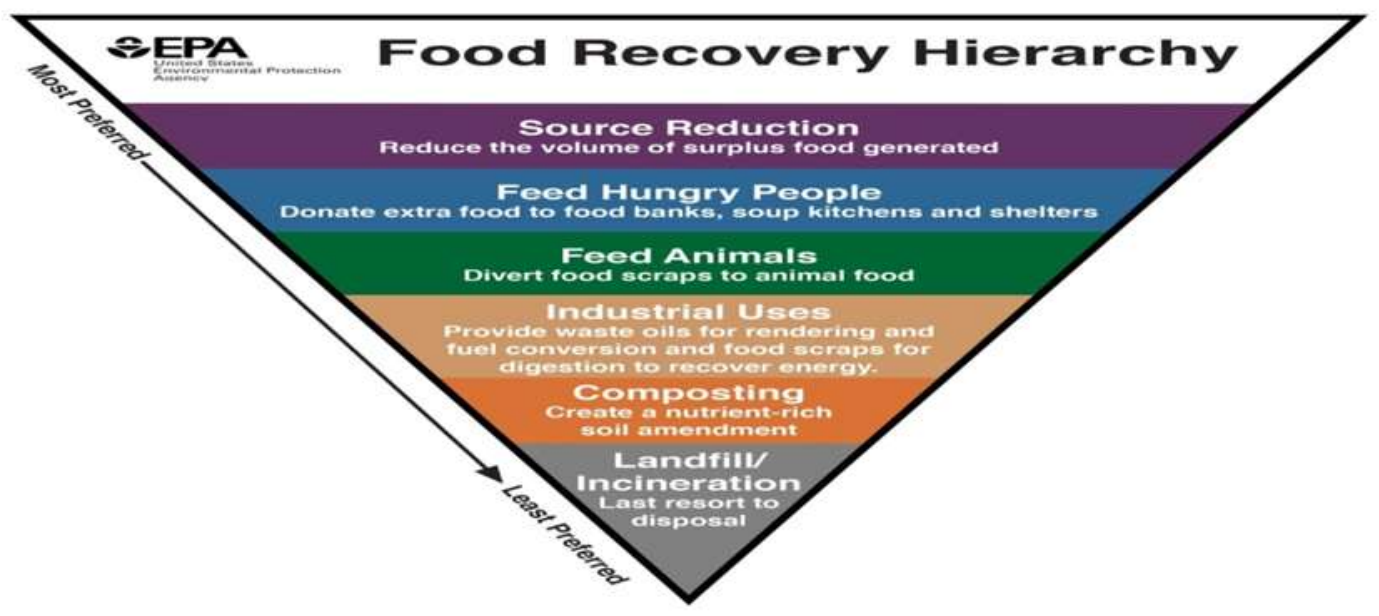

Figure (1): Food Recovery Hierarchy.

Source: USEPA (2014a).

Food Redistribution to Feed Hungry People (Reusing)

Excess food may be used in food recovery, meaning the processing of wholesome food from farmers' fields, grocery stores, or food service institutions for distribution to the poor and hungry. Surplus food may be reused as livestock feed, fertilizer, biodiesel, or other fuels. Finally, there is the possibility of disposing of the waste (Garrone et al., 2014). Waste reusing is defined as "the use of a product more than once in its same form for the same or similar purpose" (Georgia Hospitality Environmental Partnership, 1996). Whenever possible, hotels should reuse items in their original form for the same or a different purpose rather than discarding them. If an item cannot be reused on-site, the property should examine the possibility of selling or donating it to employees, charitable organizations, schools, or other interested parties (Personnel Administration Consulting Group, 2001). Redistribution is the process whereby surplus food is provided for hunger people rather than being waste. Surplus food that could legally go to people was often sent for anaerobic digestion (the process of turning FW into energy). This was encouraged by tax incentives for FW that was turned into green energy, while there was no similar financial support to enable businesses to redistribute their surplus food to hungry people. As a result of these incentives, many businesses disposed of edible surplus food via anaerobic digestion or converted it to animal feed, because this cost less than keeping it in a fit state for human consumption, which had additional costs in terms of segregation, storage, and handling (House of Commons, 2017). Most organizations consider transporting the major barrier to food donation. Food rescue organizations are usually responsible for collecting and distributing donations. Most food banks have had to heavily invest in transport infrastructure to effectively adapt to greater handling (Gunders and Bloom, 2017). Chapman et al. (2019) confirmed that food donation can be encouraged through donation tax incentives, standardized donation regulations, donation matching software, and donation transportation, storage, and handling.

\section{Using FW as Animal Feeding (Reusing)}

Bartlett (2010) declared that additional co-products or by-products are often produced during the production of the main product. Where these materials are further used, e.g. in animal feed or redistributed to charities, they are not considered waste. It is still important to minimize surpluses and the creation of by-products resulting from inefficiencies in production. USEPA (2014b) demonstrated that it may be possible to use discarded food as feed for livestock, poultry, or other animals depending on the proximity of FW generators to local farms or zoos. Lasaridi et al. (2018) and Abeliotis et al. (2018) stated that using FW for animal feeding has 
several benefits such as, it helps the implementation of source separation for FW, it reduces FW going to landfill, it is an excellent example of circular economy in which one process's waste becomes the raw material for another, and it is a process of recycling and reuse since FW is reused to produce food (meat) again. But USEPA (2014b) noted that there are barriers to using FW as animal feed include transportation restrictions, issues of liability, costs of separating FW from packaging, and concerns about the safety of animal feed.

\section{FW Recycling}

Waste recycling is defined as "the process by which materials, otherwise intended for disposal, are collected and used as raw materials for new products". Recycling prevents useful materials from being landfilled or combusted, thus saving energy and natural resources (Georgia Hospitality Environmental Partnership, 1996; Personnel Administration Consulting Group, 2001). Sushil (2018) noted that to generate compost/electricity/gas for use in the hotel, the FW and other types of waste must be segregated and recycled. House of Commons (2017) stated that the unavoidable FW is created as part of food products such as banana skins, tea bags, and egg shells. Resource Efficient Scotland (2014) demonstrated that if unavoidable FW is collected separately and sent for appropriate processing, it can be turned into useful end products such as compost and renewable energy. Hollins (2013) stated that composting is a natural process through which micro-organisms in the presence of oxygen break down organic matter, creating compost that can provide the soil with nutrients and organic matter. Personnel Administration Consulting Group (2001) mentioned that the key to a successful composting program is separating compostable materials (e.g., yard waste, vegetable cuttings, fruit peels) from noncompostable waste (e.g., plastics, meat, and fatty FW, metals) as they are generated. It is much easier to keep wastes separate from the beginning than to separate them after they are mixed.

\section{Sending $\boldsymbol{F} W$ to Landfill}

Hoornweg and Bhada-Tata (2012) stated that it is necessary to send waste or residue from other processes to a disposal site. Landfills are a common final waste disposal site and should be built and managed to protect the environment and public health. Proper landfilling is often lacking, especially in developing countries Although Bartlett (2010) confirmed that landfill is one of the least desirable management routes according to the waste hierarchy, and should be avoided wherever possible. It is also an expensive option, and many organizations consider that diverting waste from landfills can often provide both financial and environmental benefits. Especially, FW is very damaging when landfilled, releasing harmful greenhouse gases as the matter breaks down. There is also the loss of resources that went into producing the food in the first place to be considered. Abeliotis et al. (2018) confirmed that in some European Union countries, especially the southern countries, most FW ends up in landfill (e.g. in Greece, in 2013 , more than $95 \%$ of FW ended up in landfill).

\section{Research Aim and Objectives}

This research aims to explore the applied FW management polices after FW generation in three, four, and five-star hotels. To achieve the research aim; there are some objectives were targeted as follows:

1. To show hotels efforts in monitoring their generated FW.

2. To define the applied policies for managing FW in hotels.

3. To reveal the barriers that hotels face while managing FW.

4. To find out if there are differences or not between the three, four and five-star hotels in the extent of FW management policies implementation.

5. To find out if there are differences or not between chain and independent hotels in the extent of FW management policies implementation. 


\section{Research Questions}

1. What are hotels efforts in monitoring their generated FW?

2. What are the applied policies for managing FW in hotels?

3. What are the barriers that hotels face while managing FW?

4. Are there differences between the three, four and five-star hotels in the extent of FW management policies implementation?

5. Are there differences between chain and independent hotels in the extent of FW management policies implementation?

\section{Methodology}

The research adopted the deductive approach and mono-quantitative method research design using a questionnaire survey for a sample of food and beverage department managers in three, four, and five-star hotels at Hurghada city (88 participants). The questionnaire included six major sections. Section one was general data about hotels. Section two included the process of FW monitoring (six questions); it achieves the first objective and answers the first question of the research. Section three included two questions with a three-dimensional Likert scale about the process of FW reusing in hotels (donation of food and reusing food as animal feed); it achieves the second objective and answers the second question of the research. Also, Section four included two questions with a three-dimensional Likert scale about the process of FW recycling in hotels; it achieves the second objective and answers the second question of the research. Section five included one question with a three-dimensional Likert scale about the process of sending FW to landfill; it achieves the second objective and answers the second question of the research. Finally, section six included one question with a three-dimensional Likert scale about barriers to managing FW in hotels; it achieves the third objective and answers the third question of the research. The research depended on the cluster random sample in the field research. The research applied Taro Yamane equation (Yamane, 1967) to calculate the sample size from the next formula:

$$
n=\frac{N}{1+N * e 2}
$$

Where, $\mathrm{N}$ : the population size (112), n: the sample size (88), and e: the acceptable sampling error (0.05). According to the Egyptian Hotel Association (2016); the number of five, four and three star hotels in Hurghada city is 112 hotels, so the total number of population is 112 food and beverages managers. By applying the data of the research population in the previous formula, the optimal sample size of the research was calculated (88 participants). The research questionnaire was distributed in hard forms handed to 88 food and beverage department managers. Out of this number, there are 69 forms that are valid to be analyzed (representing $78.4 \%$ response rate) (see table 1 ).

Table (1): Research population and sample

\begin{tabular}{|c|c|}
\hline & Number \\
\hline Population & 112 \\
\hline Targeted sample & 88 \\
\hline Respondents & 77 \\
\hline Valid & 69 \\
\hline Response rate & $78.4 \%$ \\
\hline
\end{tabular}

Source: Developed by the researchers.

\section{Validity of the research}

A panel of experts in the field of hospitality management was consulted as a way to collect opinions and suggestions on the research tool. The researchers used face validity to ensure the 
validity of data collection instruments. Through this method, the researchers match each research objective with its question. Moreover, factor analysis was performed to improve the strength of the components.

\section{Reliability of the Research}

For reliability of survey statements, Cronbach's alpha coefficient was tested, and exceeded 0.7 for all variables as shown in table 2; this means that all items are reliable Cronbach's $\alpha$ value of all factors exceeded 0.7, referring to suitable measurement reliability. Hair et al. (2010) stated that Cronbach's $\alpha$ level of more than 0.7 is suitable for reliability.

Table (2): Reliability

\begin{tabular}{|l|c|c|}
\hline \multicolumn{1}{|c|}{ The Axis } & No. of statements & Alpha Coefficient \\
\hline Benefits of FW monitoring & 5 & 0.799 \\
\hline Uses of surplus edible food & 7 & 0.806 \\
\hline Benefits of FW reusing & 4 & 0.799 \\
\hline Places of FW recycling & 2 & 0.806 \\
\hline Outcomes of FW recycling & 4 & 0.807 \\
\hline Send FW to landfills & 1 & 0.801 \\
\hline Barriers of surplus edible food donation & 4 & 0.805 \\
\hline Barriers of FW reusing as animal feed & 4 & 0.803 \\
\hline Barriers of FW recycling & 2 & 0.801 \\
\hline
\end{tabular}

\section{The Sample Characteristics}

Table (3): The sample characteristics (hotel data)

\begin{tabular}{|l|l|c|c|c|}
\hline \multicolumn{1}{|c|}{ Variable } & \multicolumn{1}{|c|}{ Response } & Frequency & Percent & Rank \\
\hline \multirow{3}{*}{ Hotel ownership } & Independent hotel & 41 & 59.4 & 1 \\
\cline { 2 - 5 } & Chain hotel & 28 & 40.6 & 2 \\
\hline \multirow{3}{*}{ Hotel class } & Three-star & 24 & 34.8 & 2 \\
\cline { 2 - 5 } & Four-star & 28 & 40.6 & 1 \\
\cline { 2 - 5 } & Five-star & 17 & 24.6 & 3 \\
\hline
\end{tabular}

Table (3) shows that $59.4 \%$ of the sample are independent hotels (41 hotels), $40.6 \%$ of the sample are chain hotels (28 hotels). Moreover, $40.6 \%$ of the sample are four-star hotels (28 hotels), $34.8 \%$ are three-star hotels (24 hotels), and $24.6 \%$ of the sample are five-star hotels (17 hotels).

\section{FW Monitoring}

The purpose of this variable is to show hotels efforts in monitoring their generated FW. This variable aims to achieve the first objective and answer the first question of the research.

Table (4): FW collection places

\begin{tabular}{|l|c|c|c|}
\hline \multicolumn{1}{|c|}{ Variable } & Frequency & Percent & Rank \\
\hline In separate bins- for FW & 54 & 78.3 & 1 \\
\hline In bins with the other types of wastes & 15 & 21.7 & 2 \\
\hline Total & $\mathbf{6 9}$ & $\mathbf{1 0 0}$ & - \\
\hline
\end{tabular}

The survey results show that $78.3 \%$ of hotels (54 hotels) collect FW in separate bins and $21.7 \%$ (15 hotels) collect FW in bins with the other types of wastes. This result is consistent with Personnel Administration Consulting Group (2001); it is much easier to keep wastes separate from the beginning than to separate them after they are mixed.

Table (5): Weight of the daily FW in the hotel

\begin{tabular}{|l|c|c|c|}
\hline \multicolumn{1}{|c|}{ Variable } & Frequency & Percent & Rank \\
\hline Less than 25 kg per day & 9 & 13 & 3 \\
\hline Between 25 kg and 50 kg per day & 21 & 30.5 & 2 \\
\hline
\end{tabular}




\begin{tabular}{|c|c|c|c|}
\hline More than 50 kg per day & 9 & 13 & 3 \\
\hline The hotel does not weight FW & 30 & 43.5 & 1 \\
\hline Total & $\mathbf{6 9}$ & $\mathbf{1 0 0}$ & - \\
\hline
\end{tabular}

Table (5) shows that $43.5 \%$ of hotels (30 hotels) do not weight their FW, 30.5\% of them (21 hotels) waste between $25 \mathrm{~kg}$ and $50 \mathrm{~kg}$ per day. Moreover, there are $13 \%$ of hotels (9 hotels) waste less than $25 \mathrm{~kg}$ per day, Also $13 \%$ of hotels (9 hotels) waste more than $50 \mathrm{~kg}$ per day. This result is consistent with loke (2018); FW could be measured in the food supply chain in three different ways-edible weight, economic value, and equivalent calories.

Table (6): Ranking of the most wasted food groups in the hotel

\begin{tabular}{|c|c|c|c|c|c|}
\hline Variable & Response & Frequency & Percent & Sum & Rank \\
\hline \multirow{5}{*}{ Cereals and bakery products } & Fifth & 6 & 8.7 & \multirow{5}{*}{249} & \multirow{5}{*}{1} \\
\hline & Fourth & 12 & 17.4 & & \\
\hline & Third & 15 & 21.7 & & \\
\hline & Second & 6 & 8.7 & & \\
\hline & First & 30 & 43.5 & & \\
\hline \multirow{5}{*}{ Fruits and vegetable } & Fifth & 6 & 8.7 & \multirow{5}{*}{228} & \multirow{5}{*}{2} \\
\hline & Fourth & 9 & 13 & & \\
\hline & Third & 27 & 39.2 & & \\
\hline & Second & 12 & 17.4 & & \\
\hline & First & 15 & 21.7 & & \\
\hline \multirow{5}{*}{$\begin{array}{l}\text { Meat and poultry and their } \\
\text { products }\end{array}$} & Fifth & 12 & 17.4 & \multirow{5}{*}{210} & \multirow{5}{*}{3} \\
\hline & Fourth & 15 & 21.7 & & \\
\hline & Third & 9 & 13 & & \\
\hline & Second & 24 & 34.9 & & \\
\hline & First & 9 & 13 & & \\
\hline \multirow{5}{*}{ Fish and seafood } & Fifth & 24 & 34.9 & \multirow{5}{*}{171} & \multirow{5}{*}{5} \\
\hline & Fourth & 18 & 26 & & \\
\hline & Third & 9 & 13 & & \\
\hline & Second & 6 & 8.7 & & \\
\hline & First & 12 & 17.4 & & \\
\hline \multirow{5}{*}{ Dairy products } & Fifth & 21 & 30.5 & \multirow{5}{*}{177} & \multirow{5}{*}{4} \\
\hline & Fourth & 15 & 21.7 & & \\
\hline & Third & 9 & 13 & & \\
\hline & Second & 21 & 30.5 & & \\
\hline & First & 3 & 4.3 & & \\
\hline
\end{tabular}

The purpose of table (6) is to identify the ranking of food groups from the most to the least wasted in the hotel. The previous table shows that the cereals and bakery products group is the highest wasted food group; the fruits and vegetable group comes in the second rank. While fish and seafood group is the least wasted food group in hotels.

Table (7): Ranking of the most wasted food plates categories in the hotel

\begin{tabular}{|c|c|c|c|c|c|}
\hline Variable & Response & Frequency & Percent & Sum & Rank \\
\hline \multirow{5}{*}{ Appetizers and Salads } & Fifth & 6 & 8.7 & \multirow{5}{*}{270} & \multirow{5}{*}{1} \\
\hline & Fourth & - & - & & \\
\hline & Third & 12 & 17.4 & & \\
\hline & Second & 27 & 39.1 & & \\
\hline & First & 24 & 34.8 & & \\
\hline \multirow{5}{*}{ Soups } & Fifth & 9 & 13 & \multirow{5}{*}{162} & \multirow{5}{*}{5} \\
\hline & Fourth & 42 & 61 & & \\
\hline & Third & 6 & 8.7 & & \\
\hline & Second & 9 & 13 & & \\
\hline & First & 3 & 4.3 & & \\
\hline \multirow{2}{*}{ Side dishes } & Fifth & 6 & 8.7 & \multirow{2}{*}{231} & \multirow{2}{*}{2} \\
\hline & Fourth & 9 & 13 & & \\
\hline
\end{tabular}




\begin{tabular}{|c|c|c|c|c|c|}
\hline & Third & 24 & 34.9 & & \\
\hline & Second & 15 & 21.7 & & \\
\hline & First & 15 & 21.7 & & \\
\hline \multirow{5}{*}{ Main courses } & Fifth & 27 & 39.1 & \multirow{5}{*}{195} & \multirow{5}{*}{3} \\
\hline & Fourth & 3 & 4.3 & & \\
\hline & Third & 12 & 17.4 & & \\
\hline & Second & 9 & 13 & & \\
\hline & First & 18 & 26.2 & & \\
\hline \multirow{5}{*}{ Desserts } & Fifth & 21 & 30.5 & \multirow{5}{*}{171} & \multirow{5}{*}{4} \\
\hline & Fourth & 15 & 21.7 & & \\
\hline & Third & 18 & 26.1 & & \\
\hline & Second & 9 & 13 & & \\
\hline & First & 6 & 8.7 & & \\
\hline
\end{tabular}

The purpose of this table is to identify the ranking of food plate categories from the most to the least wasted in the hotel. The table shows that the appetizers and salads category is the highest wasted food plate category; the side dishes category comes in the second rank. While soups category is the least wasted food plate category in hotels.

Table (8): Ranking of the most wasted food cycle stages in the hotel

\begin{tabular}{|c|c|c|c|c|c|}
\hline Variable & Response & Frequency & Percent & Sum & Rank \\
\hline \multirow{5}{*}{ Menu planning } & Fifth & 36 & 52.2 & \multirow{5}{*}{147} & \multirow{5}{*}{5} \\
\hline & Fourth & 12 & 17.4 & & \\
\hline & Third & 6 & 8.7 & & \\
\hline & Second & 6 & 8.7 & & \\
\hline & First & 9 & 13 & & \\
\hline \multirow{5}{*}{ Food purchasing } & Fifth & 9 & 13 & \multirow{5}{*}{149} & \multirow{5}{*}{4} \\
\hline & Fourth & 39 & 56.7 & & \\
\hline & Third & 15 & 21.7 & & \\
\hline & Second & 3 & 4.3 & & \\
\hline & First & 3 & 4.3 & & \\
\hline \multirow{5}{*}{ Food storage } & Fifth & 9 & 13 & \multirow{5}{*}{213} & \multirow{5}{*}{3} \\
\hline & Fourth & - & - & & \\
\hline & Third & 39 & 56.6 & & \\
\hline & Second & 18 & 26.1 & & \\
\hline & First & 3 & 4.3 & & \\
\hline \multirow{5}{*}{ Food preparation } & Fifth & - & - & \multirow{5}{*}{294} & \multirow{5}{*}{1} \\
\hline & Fourth & 3 & 4.3 & & \\
\hline & Third & 6 & 8.7 & & \\
\hline & Second & 30 & 43.5 & & \\
\hline & First & 30 & 43.5 & & \\
\hline \multirow{5}{*}{$\begin{array}{l}\text { Food portioning and serving } \\
\text { (plate waste) }\end{array}$} & Fifth & 15 & 21.7 & \multirow{5}{*}{222} & \multirow{5}{*}{2} \\
\hline & Fourth & 15 & 21.7 & & \\
\hline & Third & 3 & 4.3 & & \\
\hline & Second & 12 & 17.4 & & \\
\hline & First & 24 & 34.9 & & \\
\hline
\end{tabular}

The previous table identifies the ranking of food cycle stages from the most to the least wasted in the hotel. The table shows that the food preparation stage is the highest wasted stage; the food portioning and serving (plate waste) stage comes in the second rank. While the menu planning stage is the least wasted in hotels.

Table (9): Factor analysis of FW monitoring benefits

\begin{tabular}{|l|c|}
\hline \multicolumn{1}{|c|}{ Statements } & Loading \\
\hline Set menus well & 0.87 \\
\hline Addressing over-portioning & 0.88 \\
\hline Improving demand forecasting & 0.82 \\
\hline
\end{tabular}




\begin{tabular}{|l|c|}
\hline Identify where FW arises & 0.79 \\
\hline Identify specific causes for FW $\quad$ Sums of squared loadings & 0.83 \\
\hline
\end{tabular}

Factor analysis shown in the previous table attempts to identify key variables that explain the pattern of correlations within a set of observed variables. Fabrigar et al. (1999) stated that statistical loading should not be less than 0.6. Factor analysis declares that all five statements are loaded on one factor explained $84 \%$ of the variance in the underlying variable of research. In other words, the previous five variables are responsible for the variance in FW monitoring benefits with a percentage of $84 \%$.

Table (10): Statistics for FW monitoring benefits

\begin{tabular}{|c|c|c|c|c|c|c|c|}
\hline Benefits of FW Monitoring & Response & Freq. & Percent & Mean* & SD & Sig. & Rank \\
\hline \multirow{3}{*}{ Set menus well } & Agree & 57 & 82.6 & \multirow{3}{*}{2.83} & \multirow{3}{*}{0.38} & \multirow{3}{*}{0.000} & \multirow{3}{*}{1} \\
\hline & Neutral & 12 & 17.4 & & & & \\
\hline & Disagree & - & - & & & & \\
\hline \multirow{3}{*}{ Addressing over-portioning } & Agree & 54 & 78.3 & \multirow{3}{*}{2.74} & \multirow{3}{*}{0.53} & \multirow{3}{*}{0.000} & \multirow{3}{*}{2} \\
\hline & Neutral & 12 & 17.4 & & & & \\
\hline & Disagree & 3 & 4.3 & & & & \\
\hline \multirow{3}{*}{$\begin{array}{l}\text { Improving } \\
\text { forecasting }\end{array}$} & Agree & 54 & 78.3 & \multirow{3}{*}{2.70} & \multirow{3}{*}{0.63} & \multirow{3}{*}{0.000} & \multirow{3}{*}{3} \\
\hline & Neutral & 9 & 13 & & & & \\
\hline & Disagree & 6 & 8.7 & & & & \\
\hline \multirow{3}{*}{ Identify where FW arises } & Agree & 42 & 60.9 & \multirow{3}{*}{2.48} & \multirow{3}{*}{0.72} & \multirow{3}{*}{0.000} & \multirow{3}{*}{4} \\
\hline & Neutral & 18 & 26.1 & & & & \\
\hline & Disagree & 9 & 13 & & & & \\
\hline \multirow{3}{*}{$\begin{array}{l}\text { Identify specific causes for } \\
\text { FW }\end{array}$} & Agree & 60 & 87 & \multirow{3}{*}{2.83} & \multirow{3}{*}{0.48} & \multirow{3}{*}{0.000} & \multirow{3}{*}{1} \\
\hline & Neutral & 6 & 8.7 & & & & \\
\hline & Disagree & 3 & 4.3 & & & & \\
\hline & verall & & & 2.71 & 0.45 & 0.000 & - \\
\hline
\end{tabular}

*Mean of benefits of FW monitoring; Where 1= disagree, 2 = neutral and 3= agree. SD = Standard Deviation and Sig. $=$ significance degree of one-sample T-Test.

Table (10) mentions that the most effective variables are "set menus well" and "identify specific causes for FW", where the mean value is (2.83) and the standard deviation is (0.38) for the variable "set menus well", although the mean value is $(2.83)$ and the standard deviation is (0.48) for the variable "identify specific causes for FW". On the other hand, the least effective variable is "Identify where FW arises", where the mean value is (2.48) and standard deviation is (0.72). The overall mean of the above variables is (2.71), the standard deviation of means values is $(0.45)$ and the p-value of the one-sample T-test is $(0.000)$ which indicates that there are significant differences between the benefits of FW monitoring and the test value (3). In other words, respondents' awareness of all variables is less than the test value. These results are consistent with Hollins (2013); using FW monitoring data regularly to set menus, address overportioning, improve demand forecasting, identify where the waste arises, and provide important information to target specific causes for FW.

\section{FW Reusing (Donation of Food and Reusing food as Animal Feed)}

The purpose of this variable is to define the applied policies concerning FW reusing. This variable aims to achieve the second objective and answer the second question of the research.

Table (11): Factor analysis of surplus edible food uses

\begin{tabular}{|l|c|}
\hline \multicolumn{1}{|c|}{ Statements } & Loading \\
\hline Donating it to the hotel staff & 0.67 \\
\hline Selling it to the hotel staff & 0.75 \\
\hline Donating it to charitable organizations & 0.73 \\
\hline Selling it to charitable organizations & 0.62 \\
\hline Using it in subsequent meals & 0.78 \\
\hline
\end{tabular}




\begin{tabular}{|c|c|}
\hline Using or selling it as animal feed & 0.69 \\
\hline Throwing it in trash bins & 0.64 \\
\hline Sums of squared loadings & 0.70 \\
\hline
\end{tabular}

Factor analysis is shown in table (11) states that all seven statements are loaded on one factor explained $70 \%$ of the variance in the underlying variable of the research. In other words, the previous seven variables are responsible for the variance in surplus edible food uses with a percentage of $70 \%$.

Table (12): Statistics for surplus edible food uses

\begin{tabular}{|c|c|c|c|c|c|c|c|}
\hline $\begin{array}{c}\text { Uses of Surplus Edible } \\
\text { Food }\end{array}$ & Response & Freq. & Percent & Mean* & SD & Sig. & Rank \\
\hline \multirow{3}{*}{ Donating it to the hotel staff } & Always & 6 & 8.7 & \multirow{3}{*}{1.61} & \multirow{3}{*}{0.65} & \multirow{3}{*}{0.000} & \multirow{3}{*}{4} \\
\hline & Sometimes & 30 & 43.5 & & & & \\
\hline & Never & 33 & 47.8 & & & & \\
\hline \multirow{3}{*}{ Selling it to the hotel staff } & Always & - & - & \multirow{3}{*}{1.09} & \multirow{3}{*}{0.29} & \multirow{3}{*}{0.000} & \multirow{3}{*}{6} \\
\hline & Sometimes & 7 & 8.7 & & & & \\
\hline & Never & $4 \pi$ & 91.3 & & & & \\
\hline \multirow{3}{*}{$\begin{array}{l}\text { Donating it to charitable } \\
\text { organizations }\end{array}$} & Always & 3 & 4.3 & \multirow{3}{*}{1.70} & \multirow{3}{*}{0.55} & \multirow{3}{*}{0.000} & \multirow{3}{*}{3} \\
\hline & Sometimes & 42 & 60.9 & & & & \\
\hline & Never & 24 & 34.8 & & & & \\
\hline \multirow{3}{*}{$\begin{array}{l}\text { Selling it to charitable } \\
\text { organizations }\end{array}$} & Always & - & - & \multirow{3}{*}{1.04} & \multirow{3}{*}{0.21} & \multirow{3}{*}{0.000} & \multirow{3}{*}{7} \\
\hline & Sometimes & 3 & 4.3 & & & & \\
\hline & Never & 66 & 95.7 & & & & \\
\hline \multirow{3}{*}{ Using it in subsequent meals } & Always & - & - & \multirow{3}{*}{1.74} & \multirow{3}{*}{0.44} & \multirow{3}{*}{0.000} & \multirow{3}{*}{2} \\
\hline & Sometimes & 51 & 73.9 & & & & \\
\hline & Never & 18 & 26.1 & & & & \\
\hline \multirow{3}{*}{$\begin{array}{l}\text { Using or selling it as animal } \\
\text { feed }\end{array}$} & Always & 3 & 4.3 & \multirow{3}{*}{1.39} & \multirow{3}{*}{0.57} & \multirow{3}{*}{0.000} & \multirow{3}{*}{5} \\
\hline & Sometimes & 21 & 30.4 & & & & \\
\hline & Never & 45 & 65.3 & & & & \\
\hline \multirow{3}{*}{ Throwing it in trash bins } & Always & 27 & 39.2 & \multirow{3}{*}{2.09} & \multirow{3}{*}{0.84} & \multirow{3}{*}{0.000} & \\
\hline & Sometimes & 21 & 30.4 & & & & 1 \\
\hline & Never & 21 & 30.4 & & & & \\
\hline & Overall & & & 1.52 & 0.51 & 0.000 & - \\
\hline
\end{tabular}

*Mean of uses of surplus edible food; Where $1=$ never, $2=$ sometimes and $3=$ always. $\mathrm{SD}=$ Standard Deviation and Sig. $=$ significance degree of one-sample T-Test.

Table (12) indicates that the most effective variable is "throwing it in trash bins", where the mean value is (2.09) and the standard deviation is (0.84). This result is not consistent with Bartlett (2010); landfill is one of the least desirable management routes according to the waste hierarchy, and should be avoided wherever possible. On the other hand, the least effective variable is "selling it to charitable organizations", where the mean value is (1.04) and the standard deviation is (0.21). This result is consistent with Personnel Administration Consulting Group (2001); the property should examine the possibility of selling or donating it to employees, charitable organizations, schools, or other interested parties. The overall mean of the above variables is (1.52), the standard deviation of means values is $(0.51)$ and the $p$-value of the one-sample T-test is $(0.000)$ which indicates that there are significant differences between surplus edible food uses and the test value (3). In other words, respondents' awareness of all variables is less than the test value.

Table (13): Factor analysis of FW reusing benefits

\begin{tabular}{|l|c|}
\hline \multicolumn{1}{|c|}{ Statements } & Loading \\
\hline The implementation of source separation for FW & 0.67 \\
\hline Reducing of FW going to landfill & 0.65 \\
\hline The hotel gets financial support for the donation of surplus edible food & 0.68 \\
\hline
\end{tabular}




\begin{tabular}{|c|c|}
\hline $\begin{array}{l}\text { The circular economy such as reusing FW as animal feed in which one process's waste becomes } \\
\text { the raw material for another }\end{array}$ & 0.69 \\
\hline Sums of squared loadings & 0.67 \\
\hline
\end{tabular}

Factor analysis is shown in table (13) states that all four statements are loaded on one factor explained $67 \%$ of the variance in the underlying variable of research. In other words, the previous four variables are responsible for the variance in FW reusing benefits with a percentage of $67 \%$.

Table (14): Statistics for FW reusing benefits

\begin{tabular}{|c|c|c|c|c|c|c|c|}
\hline Benefits of FW Reusing & Response & Freq. & Percent & Mean* & SD & Sig. & Rank \\
\hline \multirow{3}{*}{$\begin{array}{l}\text { The implementation of } \\
\text { source separation for FW }\end{array}$} & Agree & 45 & 65.2 & \multirow{3}{*}{2.52} & \multirow{3}{*}{0.72} & \multirow{3}{*}{0.000} & \multirow{3}{*}{1} \\
\hline & Neutral & 15 & 21.7 & & & & \\
\hline & Disagree & 9 & 13.1 & & & & \\
\hline \multirow{3}{*}{$\begin{array}{l}\text { Reducing of FW going to } \\
\text { landfill }\end{array}$} & Agree & 39 & 56.5 & \multirow{3}{*}{2.48} & \multirow{3}{*}{0.66} & \multirow{3}{*}{0.000} & \multirow{3}{*}{2} \\
\hline & Neutral & 24 & 34.8 & & & & \\
\hline & Disagree & 6 & 8.7 & & & & \\
\hline \multirow{3}{*}{$\begin{array}{l}\text { The hotel gets financial } \\
\text { support for the donation of } \\
\text { surplus edible food }\end{array}$} & Agree & 18 & 26.1 & \multirow{3}{*}{1.70} & \multirow{3}{*}{0.86} & \multirow{3}{*}{0.000} & \multirow{3}{*}{4} \\
\hline & Neutral & 12 & 17.4 & & & & \\
\hline & Disagree & 39 & 56.5 & & & & \\
\hline \multirow{3}{*}{$\begin{array}{l}\text { The circular economy } \\
\text { (reusing FW as animal feed } \\
\text { in one process's waste } \\
\text { becomes the raw material for } \\
\text { another) }\end{array}$} & Agree & 27 & 39.2 & \multirow[b]{3}{*}{2.35} & \multirow[b]{3}{*}{0.56} & \multirow[b]{3}{*}{0.000} & \multirow[b]{3}{*}{3} \\
\hline & Neutral & 39 & 56.5 & & & & \\
\hline & Disagree & 3 & 4.3 & & & & \\
\hline \multicolumn{4}{|c|}{ Overall } & 2.26 & 0.55 & 0.000 & - \\
\hline
\end{tabular}

*Mean of benefits of FW reusing; Where 1= disagree, 2 = neutral and 3= agree. SD = Standard Deviation and Sig. $=$ significance degree of one-sample T-Test.

Table (14) indicates that the most effective variable is "the implementation of source separation for FW", where the mean value is (2.52) and the standard deviation is (0.72). This result is consistent with Lasaridi et al. (2018) and Abeliotis et al. (2018); using FW for animal feeding has several benefits such as, it helps the implementation of source separation for FW, it reduces FW going to landfill, and it is an excellent example of circular economy in which one process's waste becomes the raw material for another. On the other hand, the least effective variable is "the hotel gets financial support for the donation of surplus edible food", where the mean value is (1.70) and the standard deviation is (0.86). The overall mean of the above variables is (2.26), the standard deviation of means values is $(0.55)$ and the p-value of the one-sample T-test is (0.000) which indicates that there are significant differences between surplus edible food uses and the test value (3). In other words, respondents' awareness of all variables is less than the test value.

\section{FW Recycling}

The purpose of this variable is to define the applied policies concerning FW recycling. This variable aims to achieve the second objective and answer the second question of the research.

Table (15): Factor analysis of FW recycling places

\begin{tabular}{|l|c|}
\hline \multicolumn{1}{|c|}{ Statements } & Loading \\
\hline In a FW recycling unit inside the hotel & 0.67 \\
\hline Outside the hotel by a contractor Sums of squared loadings & 0.67 \\
\hline \multicolumn{1}{|c|}{ Sul } \\
\hline
\end{tabular}

Factor analysis shown in table (15) states that all two statements are loaded on one factor explained $67 \%$ of the variance in the underlying variable of research. In other words, the previous two variables are responsible for the variance in FW recycling places with a percentage of $67 \%$. 
Table (16): Statistics for FW recycling places

\begin{tabular}{|c|c|c|c|c|c|c|c|}
\hline Places of FW Recycling & Response & Freq. & Percent & Mean* & SD & Sig. & Rank \\
\hline \multirow{3}{*}{$\begin{array}{l}\text { In a FW recycling unit } \\
\text { inside the hotel }\end{array}$} & Always & 6 & 8.7 & \multirow{3}{*}{1.48} & \multirow{3}{*}{0.66} & \multirow{3}{*}{0.000} & \multirow{3}{*}{2} \\
\hline & Sometimes & 21 & 30.4 & & & & \\
\hline & Never & 42 & 60.9 & & & & \\
\hline \multirow{3}{*}{$\begin{array}{l}\text { Outside the hotel by a } \\
\text { contractor }\end{array}$} & Always & 18 & 26.1 & \multirow{3}{*}{1.78} & \multirow{3}{*}{0.84} & \multirow{3}{*}{0.000} & \multirow{3}{*}{1} \\
\hline & Sometimes & 18 & 26.1 & & & & \\
\hline & Never & 33 & 47.8 & & & & \\
\hline \multicolumn{4}{|c|}{ Overall } & 1.63 & 0.60 & 0.000 & - \\
\hline
\end{tabular}

*Mean of places of FW recycling; Where $1=$ never, $2=$ sometimes and $3=$ always. SD $=$ Standard Deviation and Sig. = significance degree of one-sample T-Test.

Table (16) indicates that the most effective variable is "outside the hotel by a contractor", where the mean value is (1.78) and the standard deviation is (0.84). On the other hand, the least effective variable is "In a FW recycling unit inside the hotel", where the mean value is (1.48) and the standard deviation is (0.66). The overall mean of the above variables is (1.63), the standard deviation of means values is $(0.60)$ and the p-value of the one-sample T-test is $(0.000)$ which indicates that there are significant differences between FW recycling places and the test value (3). In other words, respondents' awareness of all variables is less than the test value.

Table (17): Factor analysis of FW recycling outcomes

\begin{tabular}{|c|c|}
\hline Statements & Loading \\
\hline Compost production & 0.94 \\
\hline Electricity generating & 0.69 \\
\hline Gas production & 0.91 \\
\hline Animal feed production & 0.62 \\
\hline Sums of squared loadings & 0.79 \\
\hline
\end{tabular}

Table (17) states that all four statements are loaded on one factor explained $79 \%$ of the variance in the underlying variable of research. In other words, the previous four variables are responsible for the variance in FW recycling outcomes with a percentage of $79 \%$.

Table (18): Statistics for FW recycling Outcomes

\begin{tabular}{|c|c|c|c|c|c|c|c|}
\hline $\begin{array}{c}\text { Outcomes of FW } \\
\text { Recycling }\end{array}$ & Response & Freq. & Percent & Mean* & SD & Sig. & Rank \\
\hline \multirow{3}{*}{ Compost production } & Always & 3 & 4.3 & \multirow{3}{*}{1.26} & \multirow{3}{*}{0.53} & \multirow{3}{*}{0.000} & \multirow{3}{*}{3} \\
\hline & Sometimes & 12 & 17.4 & & & & \\
\hline & Never & 54 & 78.3 & & & & \\
\hline \multirow{3}{*}{ Electricity-generating } & Always & - & - & \multirow{3}{*}{1.13} & \multirow{3}{*}{0.34} & \multirow{3}{*}{0.000} & \multirow{3}{*}{4} \\
\hline & Sometimes & 9 & 13 & & & & \\
\hline & Never & 60 & 87 & & & & \\
\hline \multirow{3}{*}{ Gas production } & Always & 3 & 4.3 & \multirow{3}{*}{1.30} & \multirow{3}{*}{0.55} & \multirow{3}{*}{0.000} & \multirow{3}{*}{2} \\
\hline & Sometimes & 15 & 21.8 & & & & \\
\hline & Never & 51 & 73.9 & & & & \\
\hline \multirow{3}{*}{ Animal feed production } & Always & 15 & 21.8 & \multirow{3}{*}{1.83} & \multirow{3}{*}{0.77} & \multirow{3}{*}{0.000} & \multirow{3}{*}{1} \\
\hline & Sometimes & 27 & 39.1 & & & & \\
\hline & Never & 27 & 39.1 & & & & \\
\hline & Overall & & & 1.38 & 0.46 & 0.000 & - \\
\hline
\end{tabular}

*Mean of outcomes of FW recycling; Where $1=$ never, $2=$ sometimes and $3=$ always. $\mathrm{SD}=$ Standard Deviation and Sig. $=$ significance degree of one-sample T-Test.

Table (18) indicates that the most effective variable is "animal feed production", where the mean value is (1.83) and the standard deviation is (0.77). On the other hand, the least effective variable is "electricity-generating", where the mean value is (1.13) and the standard deviation is (0.34). The overall mean of the above variables is (1.38), the standard deviation of means values is (0.46) and the p-value of the one-sample T-test is $(0.000)$ which indicates that there are significant differences between FW recycling Outcomes and the test value (3). In other 
words, respondents' awareness of all variables is less than the test value. These results are consistent with Sushil (2018); to generate compost, electricity, gas for use in the hotel, the FW and other types of waste must be segregated and recycled.

\section{Sending FW to Landfill}

The purpose of this variable is to know the extent of sending FW to landfills. This variable aims to achieve the second objective and answer the second question of the research.

Table (19): Statistics for the extent of sending FW to landfills

\begin{tabular}{|c|c|c|c|c|c|c|}
\hline Variable & Response & Freq. & Percent & Mean* & SD & Sig. \\
\hline \multirow{3}{*}{ The extent of sending FW to landfills } & Always & 21 & 30.4 & \multirow{3}{*}{2.26} & \multirow{3}{*}{0.53} & \multirow{3}{*}{0.000} \\
\hline & Sometimes & 45 & 65.3 & & & \\
\hline & Never & 3 & 4.3 & & & \\
\hline
\end{tabular}

*Mean of the extent of sending FW to landfills; Where $1=$ never, $2=$ sometimes and $3=$ always. SD $=$ Standard Deviation and Sig. $=$ significance degree of one-sample T-Test.

The previous table indicates that $65.3 \%$ of hotels ( 45 hotels) sometimes send their FW to landfills, $30.4 \%$ of them ( 21 hotels) always send their FW to landfills. On the other hand, there are $4.3 \%$ of hotels ( 3 hotels) do not send their FW to landfills. The mean value is (2.26), the standard deviation is $(0.53)$ and the p-value of the one-sample T-test is $(0.000)$ which indicates that there are significant differences between the extent of sending FW to landfills and the test value (3). In other words, respondents' awareness of all variables is less than the test value. These results are consistent with Hoornweg and Bhada-Tata (2012); it is necessary to send waste or residue from other processes to a disposal site. Landfills are a common final waste disposal site and should be built and managed to protect the environment and public health.

\section{Barriers of Managing FW}

The purpose of this variable is to reveal the barriers that hotels face while managing FW. This variable aims to achieve the third objective and answer the third question of the research.

Table (20): Factor analysis of the barriers that hotel faces while managing FW

\begin{tabular}{|l|c|}
\hline \multicolumn{1}{|c|}{ Statements } & Loading \\
\hline There is no financial support for donating & 0.73 \\
\hline The high cost of surplus food segregation, storing, transportation, and handling & 0.84 \\
\hline Legal reasons such as lack of standardized donation regulations & 0.77 \\
\hline Lack of donation matching software & 0.69 \\
\hline Transportation restrictions & 0.80 \\
\hline Legal responsibility & 0.71 \\
\hline The high cost of FW segregation, storing, transportation, and handling & 0.84 \\
\hline Concerns about the safety of animal feed & 0.78 \\
\hline The high cost of the recycling process & 0.82 \\
\hline The difficulty of separating FW from other wastes & 0.66 \\
\hline \multicolumn{1}{|c|}{ Sums of squared loadings } & $\mathbf{0 . 7 6}$ \\
\hline
\end{tabular}

Table (20) states that all ten statements are loaded on one factor explained $76 \%$ of the variance in the underlying variable of research. In other words, the previous ten variables are responsible for the variance in the barriers that hotel faces while managing $\mathrm{FW}$ with a percentage of $76 \%$.

Table (21): Statistics for the barriers that hotel faces while managing FW

\begin{tabular}{|c|c|c|c|c|c|c|c|}
\hline $\begin{array}{l}\text { Barriers of Surplus Edible } \\
\text { Food Donation }\end{array}$ & Response & Freq. & Percent & Mean* & SD & Sig. & Rank \\
\hline \multirow{5}{*}{$\begin{array}{l}\text { There is no financial support } \\
\text { for donating }\end{array}$} & Agree & 24 & 34.8 & \multirow{3}{*}{2.00} & \multirow{3}{*}{0.84} & \multirow{3}{*}{0.000} & \multirow{3}{*}{3} \\
\hline & Neutral & 21 & 30.4 & & & & \\
\hline & Disagree & 24 & 34.8 & & & & \\
\hline & Agree & 51 & 74 & \multirow{2}{*}{2.61} & \multirow{2}{*}{0.71} & \multirow{2}{*}{0.000} & \multirow{2}{*}{1} \\
\hline & Neutral & 9 & 13 & & & & \\
\hline
\end{tabular}




\begin{tabular}{|c|c|c|c|c|c|c|c|}
\hline $\begin{array}{l}\text { The high cost of surplus food } \\
\text { segregation, } \\
\text { transportation, and handling }\end{array}$ & Disagree & 9 & 13 & & & & \\
\hline \multirow{3}{*}{$\begin{array}{l}\text { Legal reasons such as lack of } \\
\text { standardized } \\
\text { regulations }\end{array}$} & Agree & 48 & 69.6 & \multirow{3}{*}{2.57} & \multirow{3}{*}{0.72} & \multirow{3}{*}{0.000} & \multirow{3}{*}{2} \\
\hline & Neutral & 12 & 17.4 & & & & \\
\hline & Disagree & 9 & 13 & & & & \\
\hline \multirow{3}{*}{$\begin{array}{l}\text { Lack of donation matching } \\
\text { software }\end{array}$} & Agree & 45 & 65.2 & \multirow{3}{*}{2.57} & \multirow{3}{*}{0.65} & \multirow{3}{*}{0.000} & \multirow{3}{*}{2} \\
\hline & Neutral & 18 & 26.1 & & & & \\
\hline & Disagree & 6 & 8.7 & & & & \\
\hline \multicolumn{4}{|c|}{ Overall } & 2.43 & 0.59 & 0.000 & - \\
\hline \multicolumn{8}{|c|}{ Barriers of FW Reusing as Animal Feed } \\
\hline \multirow{3}{*}{ Transportation restrictions } & Agree & 33 & 47.8 & \multirow{3}{*}{2.22} & \multirow{3}{*}{0.84} & \multirow{3}{*}{0.000} & \multirow{3}{*}{4} \\
\hline & Neutral & 18 & 26.1 & & & & \\
\hline & Disagree & 18 & 26.1 & & & & \\
\hline \multirow{3}{*}{ Legal responsibility } & Agree & 42 & 60.9 & \multirow{3}{*}{2.57} & \multirow{3}{*}{0.58} & \multirow{3}{*}{0.000} & \multirow{3}{*}{3} \\
\hline & Neutral & 24 & 34.8 & & & & \\
\hline & Disagree & 3 & 4.3 & & & & \\
\hline \multirow{3}{*}{$\begin{array}{l}\text { The high cost of FW } \\
\text { segregation, } \\
\text { transportation, and handling }\end{array}$} & Agree & 54 & 78.3 & \multirow{3}{*}{2.74} & \multirow{3}{*}{0.53} & \multirow{3}{*}{0.000} & \multirow{3}{*}{2} \\
\hline & Neutral & 12 & 17.4 & & & & \\
\hline & Disagree & 3 & 4.3 & & & & \\
\hline \multirow{3}{*}{$\begin{array}{l}\text { Concerns about the safety of } \\
\text { animal feed }\end{array}$} & Agree & 57 & 82.7 & \multirow{3}{*}{2.78} & \multirow{3}{*}{0.51} & & \\
\hline & Neutral & 9 & 13 & & & 0.000 & 1 \\
\hline & Disagree & 3 & 4.3 & & & & \\
\hline & verall & & & 2.58 & 0.49 & 0.000 & - \\
\hline & & $s$ of & ecycli & & & & \\
\hline & Agree & 57 & 82.6 & & & & \\
\hline The high cost of the & Neutral & 6 & 8.7 & 2.74 & 0.61 & 0.000 & 1 \\
\hline & Disagree & 6 & 8.7 & & & & \\
\hline & Agree & 48 & 69.6 & & & & \\
\hline The difficulty of separating & Neutral & 12 & 17.4 & 2.57 & 0.72 & 0.000 & 2 \\
\hline & Disagree & 9 & 13 & & & & \\
\hline & verall & & & 2.65 & 0.62 & 0.000 & - \\
\hline
\end{tabular}

*Mean of the barriers that hotel faces while managing FW; Where $1=$ disagree, $2=$ neutral and $3=$ agree. SD = Standard Deviation and Sig. = significance degree of one-sample T-Test.

According to table (21) in "barriers of surplus edible food donation", the most effective variable is "the high cost of surplus food segregation, storing, transportation, and handling", where the mean value is (2.61) and the standard deviation is (0.71). On the other hand, the least effective variable is "there is no financial support for donating", where the mean value is (2.00) and the standard deviation is (0.84). The overall mean of the variables is (2.43), the standard deviation of means values is $(0.59)$ and the p-value of the one-sample T-test is $(0.000)$ which indicates that there are significant differences between barriers of surplus edible food donation and the test value (3). In other words, respondents' awareness of all variables is less than the test value. These results are consistent with House of Commons (2017) and Gunders and Bloom (2017); there was no similar financial support to enable businesses to redistribute their surplus food to hungry people. Many businesses disposed of edible surplus food; because this cost less than keeping it in a fit state for human consumption, which had additional costs in terms of segregation, storage, and handling. Most organizations consider transporting the major barrier to food donation. Also these results are consistent with Chapman et al. (2019); food donation can be encouraged through donation tax incentives, standardized donation regulations, donation matching software, and donation transportation, storage, and handling.

Moreover, in "barriers of FW reusing as animal feed", the most effective variable is "concerns about the safety of animal feed", where the mean value is (2.78) and the standard deviation is 
(0.51). On the other hand, the least effective variable is "transportation restrictions", where the mean value is (2.22) and the standard deviation is (0.84). The overall mean of the variables is (2.58), the standard deviation of means values is $(0.49)$ and the p-value of the one-sample Ttest is (0.000) which indicates that there are significant differences between barriers of FW reusing as animal feed and the test value (3). In the other word, respondents' awareness of all variables is less than the test value. These results are consistent with USEPA (2014b); there are barriers to using FW as animal feed include transportation restrictions, issues of liability, costs of separating FW from packaging, and concerns about the safety of animal feed. Also, in "barriers of FW recycling", the most effective variable is "The high cost of the recycling process", where the mean value is (2.74) and the standard deviation is (0.61). On the other hand, the least effective variable is "the difficulty of separating FW from other wastes", where the mean value is (2.57) and the standard deviation is (0.72). The overall mean of the variables is (2.65), the standard deviation of means values is $(0.62)$ and the p-value of the one-sample Ttest is (0.000) which indicates that there are significant differences between barriers of FW recycling and the test value (3). In other words, respondents' awareness of all variables is less than the test value.

One-way ANOVA

The purpose of this test is to find out if there are statistically significant differences or not between three, four and five-star hotels in the extent of FW management policies implementation at the significance level of.05. This test achieves the fourth objective and answers the fourth question of the research.

Table (22): Differences between three, four and five-star hotels in the extent of FW management policies implementation

\begin{tabular}{|l|c|c|}
\hline \multicolumn{1}{|c|}{ FW Management Policies Implementation } & \multicolumn{2}{c|}{ Hotels Grades } \\
\cline { 2 - 3 } & F & Sig. \\
\hline Benefits of FW Monitoring & 1.034 & 0.361 \\
\hline Uses of Surplus Edible Food & 2.709 & 0.074 \\
\hline Benefits of FW Reusing & 0.101 & 0.904 \\
\hline Places of FW Recycling & 0.067 & 0.935 \\
\hline Outcomes of FW Recycling & 0.058 & 0.944 \\
\hline Barriers of Surplus Edible Food Donation & 0.264 & 0.769 \\
\hline Barriers of FW Reusing as Animal Feed & 0.633 & 0.534 \\
\hline Barriers of FW Recycling & 0.067 & 0.936 \\
\hline
\end{tabular}

Table (22) presents the one-way ANOVA to analyze the differences between three, four and five-star hotels concerning the implementation of FW management policies. The results show that the significance levels for all variables are more than 0.05 . This means that there are no statistically significant differences between three, four and five-star hotels in the extent of FW management policies implementation.

\section{Independent Sample T-Test}

The purpose of this test is to find out if there are statistically significant differences or not between chain and independent hotels in the extent of FW management policies implementation at the significance level of.05. This test achieves the fifth objective and answers the fifth question of the research. 
Table (23): Differences between chain and independent hotels in the extent of FW management policies implementation

\begin{tabular}{|c|c|c|c|c|c|c|c|}
\hline \multirow[t]{2}{*}{ Variable } & \multirow[t]{2}{*}{ Group } & \multirow[t]{2}{*}{ Mean* } & \multirow[t]{2}{*}{ SD } & \multicolumn{2}{|c|}{ Levene's Test } & \multicolumn{2}{|c|}{$\begin{array}{c}\text { T-Test for Equality of } \\
\text { Means }\end{array}$} \\
\hline & & & & $\mathbf{F}$ & Sig. & $\mathbf{t}$ & Sig. \\
\hline $\begin{array}{l}\text { Benefits of } \quad F W \\
\text { Monitoring }\end{array}$ & $\begin{array}{l}\text { Independent } \\
\text { Chain }\end{array}$ & $\begin{array}{l}2.78 \\
2.61\end{array}$ & $\begin{array}{l}0.39 \\
0.52\end{array}$ & 2.459 & 0.122 & 1.515 & 0.135 \\
\hline $\begin{array}{l}\text { Uses of Surplus Edible } \\
\text { Food }\end{array}$ & $\begin{array}{l}\text { Independent } \\
\text { Chain }\end{array}$ & $\begin{array}{l}1.53 \\
1.47\end{array}$ & $\begin{array}{l}0.23 \\
0.20\end{array}$ & 0.329 & 0.568 & 1.110 & 0.271 \\
\hline Benefits of FW Reusing & $\begin{array}{l}\text { Independent } \\
\text { Chain }\end{array}$ & $\begin{array}{l}2.34 \\
2.14\end{array}$ & $\begin{array}{l}0.52 \\
0.58\end{array}$ & 0.011 & 0.917 & 1.491 & 0.141 \\
\hline Places of FW Recycling & $\begin{array}{l}\text { Independent } \\
\text { Chain }\end{array}$ & $\begin{array}{l}1.67 \\
1.57\end{array}$ & $\begin{array}{l}0.58 \\
0.63\end{array}$ & 1.186 & 0.280 & 0.674 & 0.502 \\
\hline $\begin{array}{l}\text { Outcomes of } \mathrm{FW} \\
\text { Recycling }\end{array}$ & $\begin{array}{l}\text { Independent } \\
\text { Chain }\end{array}$ & $\begin{array}{l}1.29 \\
1.51\end{array}$ & $\begin{array}{l}0.36 \\
0.57\end{array}$ & 6.024 & 0.017 & -1.944 & 0.056 \\
\hline $\begin{array}{l}\text { Barriers of Surplus } \\
\text { Edible Food Donation }\end{array}$ & $\begin{array}{l}\text { Independent } \\
\text { Chain }\end{array}$ & $\begin{array}{l}2.51 \\
2.32\end{array}$ & $\begin{array}{l}0.53 \\
0.65\end{array}$ & 2.745 & 0.102 & 1.336 & 0.186 \\
\hline $\begin{array}{l}\text { Barriers of FW Reusing } \\
\text { as Animal Feed }\end{array}$ & $\begin{array}{l}\text { Independent } \\
\text { Chain }\end{array}$ & $\begin{array}{l}2.62 \\
2.51\end{array}$ & $\begin{array}{l}0.36 \\
0.63\end{array}$ & 5.241 & 0.025 & 0.941 & 0.350 \\
\hline $\begin{array}{lll}\text { Barriers } & \text { of } & \text { FW } \\
\text { Recycling } & & \\
\end{array}$ & $\begin{array}{l}\text { Independent } \\
\text { Chain }\end{array}$ & $\begin{array}{l}2.78 \\
2.46\end{array}$ & $\begin{array}{l}0.45 \\
0.78\end{array}$ & 14.715 & 0.000 & 2.133 & 0.037 \\
\hline
\end{tabular}

From the results shown in table (23), it is noted that there are no statistically significant differences between independent and chain hotels concerning benefits of FW monitoring, where Levene's Sig. is $(0.122)$ and t-test Sig. is $(0.135)$ which is more than $(0.05)$. There are no statistically significant differences between independent and chain hotels concerning uses of surplus edible food, where Levene's Sig. is (0.568) and t-test Sig. is (0.271) which is more than (0.05). There are no statistically significant differences between independent and chain hotels concerning benefits of FW reusing, where Levene's Sig. is (0.917) and t-test Sig. is (0.141) which is more than (0.05). There are no statistically significant differences between independent and chain hotels concerning places of FW recycling, where Levene's Sig. is (0.280) and t-test Sig. is $(0.502)$ which is more than (0.05). There are no statistically significant differences between independent and chain hotels concerning outcomes of FW recycling, where Levene's Sig. is (0.017) and t-test Sig. is (0.056) which is more than (0.05). There are no statistically significant differences between independent and chain hotels concerning barriers of surplus edible food donation, where Levene's Sig. is (0.102) and t-test Sig. is (0.186) which is more than (0.05). There are no statistically significant differences between independent and chain hotels concerning barriers of FW reusing as animal feed, where Levene's Sig. is (0.025) and ttest Sig. is (0.350) which is more than (0.05). Otherwise, it is clear from the previous table (table 23) that there are statistically significant differences between independent and chain hotels concerning barriers of FW recycling, where Levene's Sig. is (0.000) and t-test Sig. is (.037) which is less than (0.05). These differences are in favor of independent hotels $(M=2.78)$.

\section{Conclusion}

The research aims to explore the applied FW management polices after FW generation in three, four, and five-star hotels. The research adopted the deductive approach and mono-quantitative method research design using a questionnaire survey for a sample of food and beverage department managers in three, four, and five-star hotels at Hurghada city (80 participants). A three-dimensional Likert scale was applied in the research. The reliability and validity of the research tool were practically measured by using both the Cronbach's alpha coefficient and factor analysis test. Yamane formula was used to calculate the optimal sample size. The data collected was analyzed statistically using SPSS version 20. Concerning its questions, the 
current research revealed some interesting findings; $78.3 \%$ of hotels collect FW in separate bins which makes it easy to monitor well. While that $43.5 \%$ of hotels do not weight their FW, there are $30.5 \%$ of their waste between $25 \mathrm{~kg}$ and $50 \mathrm{~kg}$ per day. This result shows the large amount of FW that hotels generate. Concerning food groups; cereals and bakery products group is the highest wasted food group; while fish and seafood group is the least wasted food group in hotels. Concerning food plate categories, appetizers and salads is the highest wasted food plate category, while the soups category is the least wasted in hotels. Concerning food cycle stages, food preparation is the highest wasted stage; while the menu planning stage is the least wasted in hotels. The results shows the most important benefits of FW monitoring as follows; set menus well, identify specific causes for FW, and address over-portioning. According to the research results, the main uses of surplus edible food were throwing it in trash bins, using it in subsequent meals, and donating it to charitable organizations. The main benefits of $\mathrm{FW}$ reusing were the implementation of source separation for FW, and reduction of FW going to landfill. Concerning FW recycling places, outside the hotel by a contractor comes in the first rank, while in a FW recycling unit inside the hotel comes in the second rank. The main outcomes of FW recycling were animal feed production and gas production. $65.3 \%$ of hotels sometimes send their FW to landfills, $30.4 \%$ of them always send their FW to landfills and there are $4.3 \%$ of hotels do not send their FW to landfills. According to the research results, "the high cost of surplus food segregation, storing, transportation, and handling" was the most selected barrier in surplus edible food donation. Also "concerns about the safety of animal feed" was the most selected barrier in FW reusing as animal feed. While "The high cost of the recycling process" was the most selected barrier in FW recycling. The research confirmed that there are no statistically significant differences between three, four and five-star hotels concerning FW management policies implementation. There are no statistically significant differences between independent and chain hotels concerning FW management policies implementation except for the variable "Barriers of FW Recycling", there are statistically significant differences between independent and chain hotels. These differences are in favor of independent hotels $(M=2.78)$.

\section{Limitations and Future Research}

This research has several limitations. Firstly, this research was limited to food and beverages departments' managers in independent and chain hotels. Secondly, this research was limited to food and beverages departments' managers in three, four and five-star hotels in Hurghada city. Also, there is limitation was related to use of the quantitative approach although its effective results but using the qualitative approach would have provided more diverse and enriching results. Finally, future researchers should have to focus on FW reducing practices in kitchens, restaurants, and food stores in hotels.

\section{Implications and Recommendations}

Based on the previous results, food and beverages departments' managers should apply the Food Recovery Hierarchy model for managing the generated FW in hotels. This research suggests some recommendations for hotels managements as follows:

1. Hotels are encouraged to pay close attention to managing FW issues.

2. Hotels are encouraged to separate FW from other wastes so that it is easy to monitor and weigh.

3. Hotels are encouraged to implement FW reduction practices at all of food cycle stages, from menu planning until serving it in dishes (such as designing menus with different sizes of portions, using surplus food as part of the menu, offering smaller portions of the most wasted food groups for a slightly reduced price to reduce FW, and offering 
smaller portions of the most wasted food groups for a slightly reduced price to reduce FW).

4. Hotels should be encouraged not to send FW to landfills.

5. Hotels are encouraged to use surplus food in subsequent meals, donate or sell it to charitable organizations, donate or sell it to hotel staff and use or sell it as animal feed.

6. Hotels should be encouraged to set up recycling units to recycle FW to feed animals, produce gas, produce compost, or generate electricity.

7. Adequate financial support should be provided to hotels to be able to manage FW.

8. There should be standardized donation regulations to help hotels in donating surplus food.

9. Donation matching software should be provided to help hotels donate surplus food. 


\section{References}

Abeliotis, K., Lasaridi, K., Chroni, C., Terzis, E., Galliou, F., \& Manios, T. (2018). Environmental Impact Assessment of a Solar Drying Unit for the Production of Animal Feed from Food Waste. Retrieved from: http://uest.ntua.gr/naxos2018 /proceedings/pdf/NAXOS2018_Abeliotis_etal.pdf (accessed 24.7.2020).

Abo-Taleb, M. (2005). A Study on Benefits of Applying Waste Recycling Programs in the Hotel Industry. Unpublished doctorate thesis, Faculty of Tourism and Hotel Management, Helwan University, 50 - 77.

Bartlett, C. (2010). Mapping Waste in the Food and Drink Industry. Defra. Food and Drink Federation, London, UK. Retrieved from: www.oakdenehollins.co.uk /media/235/DEFR01_235_summary.pdf (accessed 2.11.2019).

Bio Intelligence Service (2010). Preparatory Study on Food Waste across EU 27. Technical Report. Retrieved from: https://ec.europa.eu/environment/eussd/pdf/bio foodwaste_report.pdf (accessed 15.2.2020).

Buzby, J., \& Hyman, J. (2012). Total and Per Capita Value of Food Loss in the United States. Food policy, 37(5), 561-570.

Buzby, J., Wells, H., \& Hyman, J. (2014). The Estimated Amount, Value, and Calories of Postharvest Food Losses at the Retail and Consumer Levels in the United States. Economic Information Bulletin Number 121, United States Department of Agriculture, Economic Research Service. Retrieved from: https://www.ers.usda.gov /webdocs/publications/43833/43680_eib121.pdf (accessed 13.12.2019).

Chapman, T., Fleming, K., Graham, L., Hammell, A., Lupini, M., Mack, I., \& Tillmann, M. (2019). Environmental Stewardship: Reducing Food Waste While Improving Food Security. Retrieved from: https://conservancy.umn.edu/bitstream/handle /11299/205551/RC11a-EDF\%20Consulting-Final\%20Report.pdf?sequence=4

\&isAllowed =y (accessed 27.7.2020).

Creedon, M., Cunningham, D., \& Hogan, J. (2010). Less Food Waste More Profit. A Guide to Minimising Food Waste in the Catering Sector. CIoT Clean Technology Centre, editor. Cork: CIT Press, Cork Institute of Technology. Retrieved from: https://www.foodwaste.ie/web-images/Food-Waste-Prevention-Guide.pdf (accessed 23.11.2019).

Curry, R. (2012). The Composition of Waste Disposed of by the UK Hospitality Industry (No. RES093-001). Waste and Resources Action Programme (WRAP), United Kingdom.

Egyptian Hotel Association (2016). The Egyptian Hotel Guide. Cairo, Egypt.

Fabrigar, R., Wegener, W., MacCallum, C., and Strahan,J., (1999). Evaluating the Use of Exploratory Factor Analysis in Psychological Research. Psychological Methods, 4(272299).

Gandhi, P., Kumar, S., Paritosh, K., Pareek, N., \& Vivekanand, V. (2017). Hotel Generated Food Waste and its Biogas Potential: A Case Study of Jaipur City, India. Waste and Biomass Valorization, 1-10. Retrieved from: http://001hdy2.1105.y. https.link.springer.com.mplb1ci.ekb.eg/content/pdf/10.1007\%2Fs12649-017-0153-1.pdf (accessed 24.9.2018).

Garrone, P., Melacini, M., \& Perego, A. (2014). Opening the Black Box of Food Waste Reduction. Food policy, 46, 129-139.

Georgia Hospitality Environmental Partnership (1996). Waste Reduction in Hotels and Motels: A Guide for Hotel and Motel Managers. Retrieved from: https://p2infohouse.org/ref/04/03266.pdf (accessed 23.3.2019).

Gunders, D., \& Bloom, J. (2017). Wasted: How America is losing up to 40 percent of its Food from Farm to Fork to Landfill. Retrieved from: https://www.ccrrc.org/wpcontent/uploads/sites/24/2014/03/wasted-food-IP.pdf (accessed 24.7.2020). 
Hair, J. F., Black, W. C., Babin, B. J., Anderson, R. E., \& Tatham, R. L. (2010). Multivariate Data Analysis New Jersy: Pearson Education.

Herszenhorn, E., Quested, T., Easteal, S., Prowse, G., Lomax, J., \& Bucatariu, C. (2014). Prevention and Reduction of Food and Drink Waste in Businesses and HouseholdsGuidance for Governments, Local Authorities, Businesses and Other Organizations. Retrieved from: http://www.fao.org/fileadmin/user_upload/save-food/PDF/Guidancecontent.pdf (accessed 20.11.2018).

High Level Panel of Experts (HLPE) (2014). Food Losses and Waste in the Context of Sustainable Food Systems. A Report by the High Level Panel of Experts on Food Security and Nutrition of the Committee on World Food Security, Rome. Retrieved from: http://www.fao.org/3/a-i3901e.pdf (accessed 2.11.2019).

Hollins, O. (2013). Overview of Waste in the UK Hospitality and Food Service Sector. Waste and Resources Action Programme: Banbury, UK. Retrieved from: http://www.wrap.org.uk/sites/files/wrap/Overview\%20of\%20Waste\%20in\%20the\%20U K\%20Hospitality\%20and\%20Food\%20Service\%20Sector\%20FINAL.pdf (accessed 29.11.2019).

Hoornweg, D., \& Bhada-Tata, P. (2012). What a Waste: A Global Review of Solid Waste Management. Retrieved from: https://openknowledge.worldbank.org/bitstream/handle/10986/17388/68135.pdf?sequen $\mathrm{ce}=8$ \&isAllowed $=\mathrm{y}($ accessed 15.2.2020).

HOTREC Hospitality Europe (2017). European Hospitality Industry Guidelines to Reduce Food Waste and Recommendations to Manage Food Donations. Retrieved from: https://www.hotrec.eu/wp-content/customer-

area/storage/21a961c993e5f7814dcb7c30d425cb95/HOTREC-guidelines-on-foodwaste-reduction-and-recommendations-to-manage-food-donations-19-January-2017.pdf (accessed 11.11.2019).

House of Commons (2017). Food Waste in England. Environment, Food and Rural Affairs Committee Report. Retrieved from: https://publications.parliament.uk/pa /cm201617/cmselect/cmenvfru/429/429.pdf (accessed 16.9.2019).

International Tourism Partnership (2014). Reducing and Managing Food Waste in Hotels. Retrieved from: http://www.greenhotelier.org/know-how-guides/reducing-andmanaging-food-waste-in-hotels/ (accessed 2.11.2019).

Lasaridi, K., Abeliotis, K., Manios, T., Zorpas, A., Chroni, C., \& Terzis, E. (2017). Food Waste Prevention in the Hospitality Sector: Prospects and Challenges. Retrieved from: uest.ntua.gr/athens2017/proceedings/pdfs/Athens2017_Lasaridi_Abeliotis_Manios_Zor pas_Chroni_Terzis.pdf (accessed 11.11.2019).

Lasaridi, K., Terzis, E., Georganti-Ntaliape, A., Fortatos, S., Panteli, P., \& Manios, T. (2018). The LIFE Food for Feed Project-An Innovative Process for Transforming Hotel's Food Waste into Animal Feed. Retrieved from: uest.ntua.gr/naxos2018/ proceedings/pdf/141_NAXOS2018_Lasaridi_etal.pdf 9accessed 23.2.2020).

Lebersorger, S., \& Schneider, F. (2011). Discussion on the Methodology for Determining Food Waste in Household Waste Composition Studies. Waste Management, 31(9-10), 19241933.

Loke, M. (2018). Food Waste: Metrics, Effects, and Hunger in Hawai'i. Springer International Publishing AG 2018. Retrieved from: https://link.springer.com/content/pdf/10.1007/9783-319-40007-5_2-2.pdf (accessed 19.6.2020).

Marthinsen, J., Sundt, P., Kaysen, O., \& Kirkevaag, K. (2012). Prevention of Food Waste in Restaurants, Hotels, Canteens and Catering. Nordic Council of Ministers. Retrieved from: http://www.diva-portal.org/smash/get/diva2:701203/FULLTEXT01.pdf (accessed 11.11.2019). 
Nedyalkova, S. (2016). Applying Circular Economy Principles to Sustainable Tourism Development. Paper presented at the PM4SD European Summer School-Abstract and Conference Proceedings, Akureyri. 38-44. Retrieved from: https://eventos.segittur .es/_files/_event/_19238/_editorFiles/file/24093_Nedyalkova_15_06\%20Circular_touri sm_Savina.pdf (accessed 24.7.2020).

Personnel Administration Consulting Group (2001). Waste Management; What You Need to Know: Small Hotels Toolkit Series. Retrieved from: http://www .caribbeanhotelandtourism.com/downloads/CHTAEF_WasteManagement.pdf (accessed 23.3.2019).

Resource Efficient Scotland (2014). Managing Food Waste in the Hospitality and Food Service Industry. Retrieved from: https://www.olleco.co.uk/docs/default-source/ downloads/managing-food-waste-in-the-hospitality-amp-food-service-industrydoc.pdf?sfvrsn=2 (accessed 18.12.2019).

Saputri, E., Rojroongwasinkul, N. \& Tangsuphoom, N. (2018). Quantity and Composition of Food Waste in Canteens of Mulawarman University, Indonesia. The International Conference on Food and Applied ,Bioscience 2018 Proceeding Book. Retrieved from: http://202.28.24.38/Data/ImageData/fi_1515151437.pdf (accessed 15.2.2019).

Selin, J. (2018). Towards Reducing Food Waste in a Hotel Breakfast Buffet: A Case Study of Profil Hotels Calmar Stadshotell. Master Research Thesis of Tourism and Sustainability, Linnaeus University, Sweden. p. ii. Retrieved from: http://www.divaportal.org/smash/get/diva2:1222754/FULLTEXT01.pdf (accessed 14.2.2020).

Sushil, P. (2018). Managing Lifetime Wastivity. Global Journal of Flexible Systems Management, 19(3), 187-189.

United States Environmental Protection Agency (USEPA) (2014a). Reducing Wasted Food \& Packaging: A Guide for Food Services and Restaurants. Retrieved from: https://nepis.epa.gov/Exe/ZyPDF.cgi/P100I7UW.PDF?Dockey=P100I7UW.PDF (accessed 9.10.2018).

United States Environmental Protection Agency (USEPA) (2014b). Food Waste Management Scoping Study. Office of Resource Conservation and Recovery. Retrieved from: https://www.epa.gov/sites/production/files/2016-01/documents/msw_task11-

2_foodwastemanagementscopingstudy_508_fnl_2.pdf (accessed 25.11.2019).

Waste and Resources Action Programme (WRAP) (2011). The Composition of Waste Disposed of by the UK Hospitality Industry. Retrieved from: http://www.wrap.org.uk /sites/files/wrap/The_Composition_of_Waste_Disposed_of_by the_UK_Hospitality_In dustry_FINAL_JULY_2011_GP_EDIT.54efe0c9.11675.pdf (accessed 2.11.2019).

Yamane T. (1967). Statistics: An Introductory Analysis. $2^{\text {nd }} e d$. New York: Harper and Row.

Youngs, A., Nobis, G., \& Town, P. (1983). Food Waste from Hotels and Restaurants in the U.K. Waste Management and Research, 1(4), 295-308. 